\title{
The Manufacture and Service Companies Differ Leverage Impact to Financial Performance
}

\author{
Intan Shaferi ${ }^{1,2}$, Sugeng Wahyudi ${ }^{1}$, Wisnu Mawardi ${ }^{1}$, Riskin Hidayat ${ }^{3}$ \& Intan Puspitasari ${ }^{4}$ \\ ${ }^{1}$ Faculty of Economics and Business, Diponegoro University, Indonesia \\ ${ }^{2}$ Faculty of Economics and Business, Jenderal Soedirman University, Indonesia \\ ${ }^{3}$ STIE YPPI Rembang, Indonesia \\ ${ }^{4}$ Muhammadiyah Purworejo University, Indonesia \\ Correspondence: Intan Shaferi, Faculty of Economics and Business, Diponegoro University, Indonesia. Tel: \\ 62-8122-708-782.
}

Received: October 15, 2019

Accepted: November 18, 2019

Online Published: March 17, 2020

doi:10.5430/ijfr.v11n2p281

URL: https://doi.org/10.5430/ijfr.v11n2p281

\begin{abstract}
The purpose of this research is to examine the leverage from firm. The firms use leverage to expand their source of fund by using external fund such as debt. By using debt, financial performance of the firm will develop. Beside the leverage, the use of size and inflation are also considered to be the factors that influence the financial performance while the firms are using leverage. As an independent variable, size is reflected by the assets and the leverage or debt by using the debt ratio to the total of assets. Then, the financial performance is reflected by using the return on the measured assets. Inflation as a control variable is included in this research to know the effect towards the financial performance. In this research, firms are divided into two sectors, there are manufacture and service sector. By using the manufacture and service sectors in order to know each effect of leverage toward the financial performance, this research focuses to the unique characteristic of these two sectors. Knowing which sector is influenced more by the leverage than the others, will guide the urgency of this research. This research used the pooled data regression method, 468 data entries of 156 listed firms in Indonesian Stock Exchange. This research was conducted from 2015 until 2017. The result shows that leverage significantly has a negative effect toward the financial performance and the size positively influences financial performance. Manufacture sector is influenced more in leverage towards the financial performance, and the service sector is influenced more on size towards the financial performance.
\end{abstract}

Keywords: financial performance, manufacture, service setor, financing, leverage, and size

\section{Introduction}

One of the main role in organization is financial decision. The decision is related to financing, investment, and dividend. Financing decision has an urgent matter due to the financial source of a firm. This matter because every decision has an impact related to the firm's financial performance.

Nowadays, a phenomenon of financing source has a trend. It is using leverage that harmonizes with the increasing number of financial institution (Halit, 2005; Hall, Foxon, \& Bolton, 2016; Hanssens, Deloof, \& Vanacker, 2016; Harel, 2016; Hashim, Mahadi, \& Amran, 2015; Ibrahim \& Mirakhor, 2014; Weill, 2008). Financing sources include internal and external source. Internal source has less impact to other parties because all the decision is not related each other. Internal source is using their own fund. At the same time using external source can be one benefit, but it also has some impacts because the obligation of paying interest has the debt period. One kind of way, some firms going go public to collect external source of fund by isuing stock (Ching, Teh, San, \& Hoe, 2015). The other uses another kind of external source beside stock, such as debt. Knowing the most relevant source to a firm, we can figure out by the characteristic of a firm and its ability to obey the rules of financial institution. Every decision has their certain risk and the one who can see some better ways will get the potential of getting great financial performance.

Financial performance is a top result of firm. This part is related to financial term, that is interpreted by the return on assets or return on equity or other measurement of profitability (Ahmad \& Qais, 2017; Kebewar, 2012, 2013; Memon, Bhutto, \& Abbas, 2012). Financial performance of a firm can be seen as an achievement, which means a success indicator of a firm. The result offinancial performance will be detected as a potential indicator to the next 
period of firm's financial performance. This is a good signal to other parties that firm can have other benefit such as increasing source of fund and expansion to the wider market.

Previous studies explain the significant result of leverage and financial performance. It has a positive relationship (Memon et al., 2012). Other side, some researches show the negative result between leverage and financial performance (Kebewar, 2012, 2013; Khasawneh \& Dasouqi, 2017; ShEluntcova, 2014; Vithessonthi \& Tongurai, 2015a, 2015b).

In this research, besides leverage and financial performance, size of the firm and sector catagory are also considered as the variables that are related to the financial performance of the firm (Ahmad \& Qais, 2017; Memon et al., 2012). Different sector catagory gives the clue to other parties to analyze which sector give the higher financial performance than the others. In this research, sector is divided into two categories, named manufacture and service.

There are some influencing factors in an active firm. The internal factors are related to the characteristics of the company and the external factors include macro factors such as inflation. In this research, inflation is the control variables. So that, this research examine the impacts of leverage, size, and inflation to financial performance based on the firm sectors.

\section{Literature Review and Hypothesis Development}

Packing order theory explains that company will borrow to fund their financing then issue the equity when internal cash flow is insufficient to fund the expenditure. Equity is less prefer to funding (Myers, 1984) and Jensen explains the relationship between agent and principle (Jensen \& Meckling, 1976). Thus, the agency problems rise when two parties have different interest for the company. When the principle decides to use the source of external fund, it may be different to the agent. The agent's willingness is to maximize the profit and the principle needs the welfare.

Some researchers result that leverage has positive relationship with the financial performance because the use of leverage can reduce the free cash flow and increasing the firm's value (Lili, Wei, \& Lin, 2011). Thus, each researcher has different opinion of leverage through the financial performance.

The previous research explains that relationship between leverage and performance that has negative impact (Kebewar, 2012, 2013; Khasawneh \& Dasouqi, 2017; Lili et al., 2011; Memon et al., 2012; Vithessonthi \& Tongurai, 2015a, 2015b). The other researchers suggest that there is a positive relationship between leverage and financial performance (Vithessonthi \& Tongurai, 2015a, 2015b).

The previous research in French from Gonzales, that leverage has positive relationship with operating performance, because the role of debt mechanism force to be efficient (González, 2013). Moreover, the effects vary in all country. In the same research, the negative effect of leverage to financial performance is revealed because of the economic condition. In the economic regression condition, the effect is negative. It has the same result with the country that has strong restriction of legal enforcement and high protection of shareholder rights (González, 2013). It means that the macro factors includes the reserach.

The research from another the previous study, conducted in Thailand within 159,375 of non-financial firms, explains that firm's leverage is negatively associated with financial performance. Hence, the details in firms' orientation mention that firms with international orientation have positive effect to financial performance and the negative effects are associated with the firm which has domestic orientation (Vithessonthi \& Tongurai, 2015b).

Other research that is conducted in manufacture textile sector in Pakistan within 141 firms conclude that leverage has negative relationship with the financial performance. High leverage leads to lower return on assets (Memon et al., 2012).

Based on the previous research, leverage has relationship with financial performance. Hypothesis stated as below:

H1. There is a negative relationship between leverage and financial performance.

The other research result that the leverage is negatively associated to financial performance. This research is held in Thailand within 170,013 firms. Total firms joined in analyzing this, explain that result. But particularly, this result is caused by firm size effect, whereas small firms tent to have positive effect of leverage to work performance, and large firms shows the opposite (Vithessonthi \& Tongurai, 2015a). It means that firm size that in this research is due to the effect to performance.

Based on the previous research, size has a positive relationship with performance. Hypothesis stated as below:

$\mathrm{H} 2$. There is a positive relationship between size and financial performance.

Thus, the used variables and relationship among variables can be shown below. 


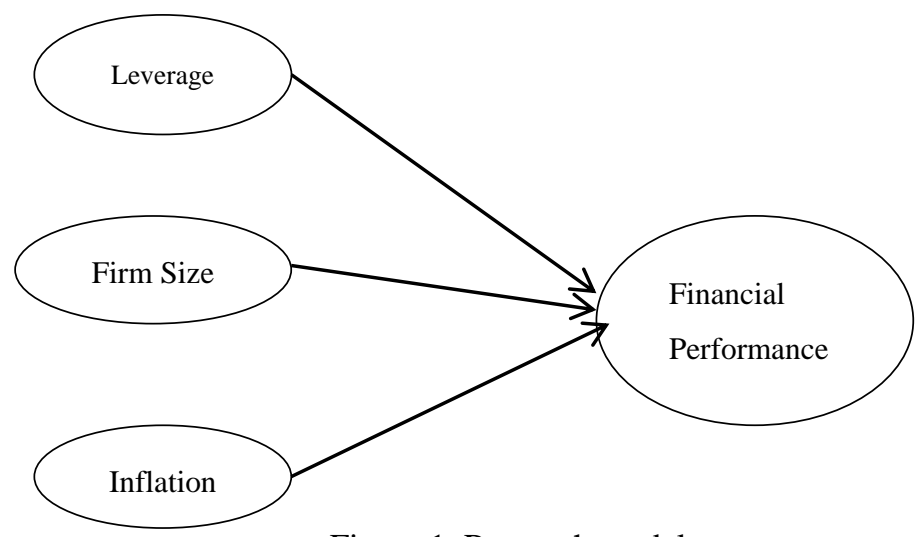

Figure 1. Research model

\section{Research Methodology}

This study examined the relationship between leverage and financial performance. Model was built based on the finding of the previous research and literature. Leverage and firm size were the independent variables, inflation was the control variable and the financial performance was the dependent variable.

This research used panel data of the companies that were listed in Indonesian Stock Exchange of three years research period during 2015 until 2017. The model that included some variables related to the financial performance is shown as follow:

$$
\mathrm{FP}=\beta_{0}+\beta_{1} \operatorname{Lev}_{\mathrm{it}}+\beta_{2} \mathrm{FS}_{\mathrm{it}}+\beta_{3} \operatorname{Lev}_{\mathrm{it}} * \text { Sector }_{\mathrm{k}}+\beta_{4} \mathrm{FS} * \text { Sector }_{\mathrm{k}}+\beta_{5} \text { Inf }+\mu_{\mathrm{it}}
$$

Where FP is financial performance as dependent variable. The financial performance was reflected by Return on Assets (ROA). ROA was calculated by ratio of net income to total assets. Return on Assets indicated profit when higher net income came from its total assets and it showed efficiency. As an independent variable, FS is firm size that was measured by natural logarithm of total assets. This measurement was used because the total assets can reflect the whole firm. Then Lev is leverage was calculated as ratio of total debt to total assets. It showed firm with the higher debt guaranteed by total assets. It indicated the risk of firm. The last variable that was used in this research was inflation. Inflation was the control variable. It was measured by percentage rate of inflation from central bank of Indonesia. Sector was divided by manufacture and service, with mark 0 for manufacture and 1 for service sector. Here, sector as unique characteristic distinguished with other research, and the sector used dummy variable.

This research willingness was to know which sector was the influenced by leverage and size to financial performance. All the variable's measurement entered in the empirical model for this research. Empirical model used in this research shown below.

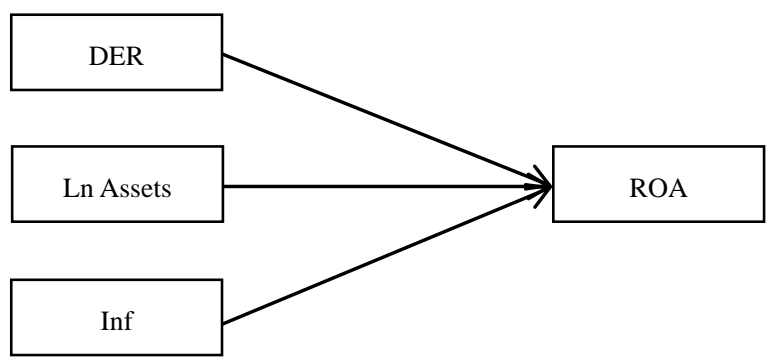

Figure 2. Empirical research model

\section{Result and Discussion}

According to the objective of this study, the panel data regression analysis was used to examine the relationship of each variable to the dependent variable. By the data panel regression, there were 468 data entries from 156 
companies listed in Indonesian Stock Exchange during 3 years reserach period of 2015 until 2017, the result was shown in table 1.

All the variable's measurement were entered in the empirical model for this research. Empirical model that was used in this research shown below. Model includes some variables related to firm's performance shown as follow:

$$
\mathrm{FP}=\beta_{0}+\beta_{1} \operatorname{Lev}_{\text {it }}+\beta_{2} \mathrm{FS}_{\text {it }}+\beta_{3} \operatorname{Lev}_{\mathrm{it}} * \mathrm{DS}_{\mathrm{k}}+\beta_{4} \mathrm{FS} * \mathrm{DS}_{\mathrm{k}}+\beta_{5} \mathrm{Inf}+\mu_{\mathrm{it}}
$$

Where FP is financial performance as dependent variable. The financial performance was reflected by Return on Assets (ROA). ROA was calculated by ratio of net income to total assets. Return on Assets indicated profit when higher net income came from its total assets and it showed efficiency. As an independent variable, FS is firm size that was measured by natural logarithm of total assets. This measurement was used because the total assets can reflect the whole firm. Then Lev is leverage was calculated as ratio of total debt to total assets. It showed firm with the higher debt guaranteed by total assets. It indicated the risk of firm. Then Firm Size which reflected by natural logaritm of assets. The last variable that was used in this research was inflation. Inflation was the control variable. It was measured by percentage rate of inflation from central bank of Indonesia. Then, the distinguish for sector was dummy variabel for sector or DS, divided by manufacture and service, with mark 0 for manufacture and 1 for service. Here, sector as unique characteristic distinguished with other research, and the sector used dummy variable. This research willingness was to know which sector was the influenced by leverage and size to financial performance.

Table 1. Regression output

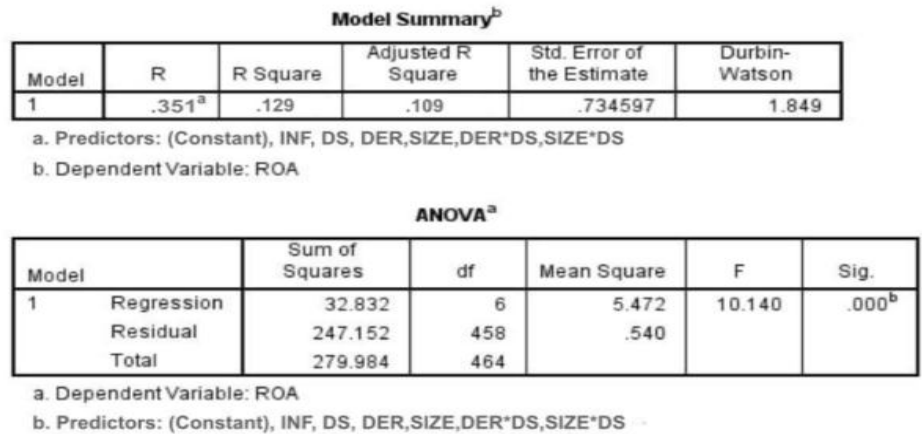

The result showed that the coefficient of determination was 0,129. It meant that DER, Size and inflation and sectors influenced ROA $12.9 \%$ and the rest was influenced by other factors and it was not included in the research. All variables were significant, the value below was 0.05 . From the table 1 , the model dealt with this research with $\mathrm{F}$ calculated 10,140 and Sig. 0.00 .

Table 2. Output result

\begin{tabular}{|c|c|c|c|c|c|c|c|c|}
\hline \multicolumn{9}{|c|}{ Coefficients $^{\mathrm{a}}$} \\
\hline \multirow{2}{*}{\multicolumn{2}{|c|}{ Model }} & \multicolumn{2}{|c|}{ Unstandardized Coefficients } & \multirow{2}{*}{$\begin{array}{c}\begin{array}{c}\text { Standardized } \\
\text { Coefficients }\end{array} \\
\text { Beta }\end{array}$} & \multirow[b]{2}{*}{$t$} & \multirow[b]{2}{*}{ Sig. } & \multicolumn{2}{|c|}{ Collinearity Statistics } \\
\hline & & B & Std. Error & & & & Tolerance & VF \\
\hline \multirow[t]{7}{*}{1} & (Constant) & .125 & 1.223 & & .102 & .919 & & \\
\hline & DER & -400 & .076 & .481 & .5 .262 & .000 & .231 & 4.330 \\
\hline & SIZE & .093 & .042 & .178 & 2.238 & .026 & .305 & 3.283 \\
\hline & DS & 3.393 & 1.470 & 1.948 & 2.308 & .021 & .104 & 9.640 \\
\hline & DER'DS & .370 & .087 & .713 & 4.269 & .000 & .224 & 4.468 \\
\hline & SIZE*DS & -165 & .050 & -2.762 & .3 .276 & .001 & .114 & 8.747 \\
\hline & INF & .040 & .014 & .126 & 2.853 & .005 & .995 & 1.005 \\
\hline
\end{tabular}

a. Dependent Variable: ROA

Table 2 showed the result for each variable, that $t$ calculated for Lev that is reflected by DER was $-5,262$. It was 
compared to $t$ table which value is $\mathrm{df}=1,652$. From the result, it was indicated that variable was significant. Same result for Firm Size that is reflected by Size that had t calculated 2,238 that above 1,652. The inflation that reflected by INF was also significant with $t$ calculated 2,853. Significance was also shown from Sig. value for Lev 0,000, FS 0,026 , and inflation 0,005 . This value is under the alpha value of 0.05 .

According to the regression output, the coefficient for Lev is from DER refers to value of coeffiicient -0,400. It meant the negative correlation between leverage and financial performance. This result supported the previous research (Kebewar, 2012, 2013; Khasawneh \& Dasouqi, 2017; Vithessonthi \& Tongurai, 2015a, 2015b). Leverage was an external source of fund, where each firms would take if it was necessary and beneficial. The result was negative. It dealt with the hypothesis. This result can be conducted because the firm is a large company and it has already high profitability and the firm used it as the internal source of fund, so that the packing order theory can be explained here as result. The more agency cost, the more lead to the negative work performance (Memon et al., 2012).

The other variable was size. The result showed that size was associated positively significant to financial performance. According to the regression output, the coefficient for FS from Size was 0,093. It meant the positive correlation between firm size and financial performance. This result supported the previous research (Ahmad \& Qais, 2017; Memon et al., 2012; Vithessonthi \& Tongurai, 2015a). The hypothesis was proven. The firms with higher total assets potentially had a higher opportunity to expand and had strong financial position. Analyzing the firm's assets showed the evidence that higher assets lead higher performance. It could happen because the firms could maximize the assets for all the activities to expand and develop the firm. It would have a better market and one step to get higher profit. So, the financial performance was greater than the firm with the minimum assets. The minimum assets would strict the developing movement and border the financial performance. According to the regression output, the coefficient for inflation was 0.04 . It meant the positive correlation between inflation and financial performance.

Thus, from the regression result, the equation exhibits below.

$$
\mathrm{FP}=\beta_{0}-0,400 \mathrm{Lev}_{\text {it }}+0,093 \mathrm{FS}_{\text {it }}+0,370 \mathrm{LevDS}_{\text {it }}-0,165 \mathrm{FSDS}_{\mathrm{it}}+0,04 \mathrm{INF}_{\text {it }}
$$

The function of sector in this research was to know which sector gave influences in the firms. The listed companies ink Indonesia Stock Exchange were divided into main sector, industry sector, and service sector. In this research there were 156 firms available as the data. Then there were 468 data entries which consisted of 289 manufacture sectors and 179 service sectors. Here, Lev influenced more in manufacture sector than service sector. Thus, the previous research (Khasawneh \& Dasouqi, 2017) mentioned that the manufacture tent to have leverage influence than service sector.

Size also had the role in the financial performance. Analyzing the service sector firms in the Indonesian Stock Exchange, showed that the size of service sector firm was influenced by the financial performance more than the manufacture sector. The larger firms had changed to develop more and achieved the greater profit. Thus, service sector nowadays improved well in some sub sector because of the technology. Hence, this research gave the evidences for it.

\section{Conclusion}

This research examines the relationship among leverage, size and inflation to the financial performance with sector as the distinguish variable that can be considered. As the firms use panel data, the result indicates that size is a matter for a firm to access the leverage that influences the financial performance.

The sector for manufacture has greater effect in leverage to the financial performance. Then service is a greater financial performance that is related to size. Leverage is significantly has negative effect to the financial performance. Then size is significantly positive to the financial performance. The next research could handle each sector detailly and have more variables that influence to the performance.

\subsection{Implication}

Leverage is used by the firm for external source of fund. This is match to the packing order theory that explain for the financial source. Using internal first then if it is needed using the external source wheather debt or equity. Thus, debt used as leverage for the firm in this reseach affecting the financial performance. That are support some previous researchs.

Then, in practice, the sectors are distingushed that the financial performance for manufacture is greather for the used of leverage. So that the service sector is greater when related to the firm size.

\subsection{Research Limitation}

This research has limitation due to the variables included, which are three variables from internal and external factors. It still has the other factors affecting the financial performance in manufacture and service sectors. Thus, for the 
consideration in the next reserach.

\subsection{Future Direction for Research}

Next research suggests more variables included in the research, both independent or control variables. Then research will more detail for breakdown the sector into subsectors. Thus will guide the research generate the conclusion for the research.

\section{References}

Ahmad, Y. K., \& Qais, A. D. (2017). Sales nationality and debt financing impact on firm's performance and risk: Evidence from Jordanian companies. EuroMed Journal of Business, 12(1), 103-126. https://doi.org/10.1108/EMJB-05-2016-0015

Ching, C. P., Teh, B. H., San, O. T., \& Hoe, H. Y. (2015). The Relationship among Audit Quality, Earnings Management, and Financial Performance of Malaysian Public Listed Companies. International Journal of Economics \& Management, 9(1).

González, V. M. (2013). Leverage and corporate performance: International evidence. International Review of Economics \& Finance, 25, 169-184. https://doi.org/10.1016/j.iref.2012.07.005

Halit, G. (2005). Comparison of debt financing between international and domestic firms: Evidence from Turkey, Germany and UK. International Journal of Managerial Finance, 1(1), 49-68. https://doi.org/10.1108/17439130510584883

Hall, S., Foxon, T. J., \& Bolton, R. (2016). Financing the civic energy sector: How financial institutions affect ownership models in Germany and the United Kingdom. Energy Research \& Social Science, 12, 5-15. https://doi.org/10.1016/j.erss.2015.11.004

Hanssens, J., Deloof, M., \& Vanacker, T. (2016). The evolution of debt policies: New evidence from business startups. Journal of Banking \& Finance, 65, 120-133. https://doi.org/10.1016/j.jbankfin.2016.01.008

Harel, R., \& Kaufmann, D. (2016, May). Financing innovative SMEs of traditional sectors: the supply side. EuroMed Journal of Business, 11(1), 84-100. https://doi.org/10.1108/EMJB-02-2015-0007

Hashim, F., Mahadi, N. D., \& Amran, A. (2015). Corporate Governance and Sustainability Practices in Islamic Financial Institutions: The Role of Country of Origin. Procedia Economics and Finance, 31, 36-43. https://doi.org/10.1016/S2212-5671(15)01129-6

Ibrahim, M. H., \& Mirakhor, A. (2014). Islamic finance: An overview. Pacific-Basin Finance Journal, 28, 2-6.

Jensen, M. C., \& Meckling, W. H. (1976). Theory of the Firm: Managerial Behavior, Agency Costs and Ownership Structure. Journal of Financial Economics, 3(4), 305-360. https://doi.org/10.1016/0304-405X(76)90026-X

Kebewar, M. (2012). The effect of debt on corporate profitability: Evidence from French service sector.

Kebewar, M. (2013). Does debt affect profitability? An empirical study of French trade sector.

Khasawneh, A. Y., \& Dasouqi, Q. A. (2017). Sales nationality and debt financing impact on firm's performance and risk: Evidence from Jordanian companies. EuroMed Journal of Business, 12(1), 103-126.

Lili, W., Wei, L., \& Lin, J. (2011). The impact of attitude variables on the credit debt behavior. Nankai Business Review International, 2(2), 120-139. https://doi.org/10.1108/20408741111139909

Memon, F., Bhutto, N. A., \& Abbas, G. (2012). Capital structure and firm performance: A case of textile sector of Pakistan. Asian Journal of Business and Management Sciences, 1(9), 9-15.

Myers, S. C. (1984). The capital structure puzzle. The Journal of Finance, 39(3).

ShEluntcova, M. (2014). Capital Structure of Private Pharmaceutical Companies in Russia. International Journal of Economics \& Management, 8(2).

Vithessonthi, C., \& Tongurai, J. (2015a). The effect of firm size on the leverage-performance relationship during the financial crisis of 2007-2009. Journal of Multinational Financial Management, 29, 1-29.

Vithessonthi, C., \& Tongurai, J. (2015b). The effect of leverage on performance: Domestically-oriented versus internationally-oriented firms. Research in International Business and Finance, 34, 265-280.

Weill, L. (2008). Leverage and corporate performance: does institutional environment matter?. Small Business Economics, 30(3), 251-265. https://doi.org/10.1007/s11187-006-9045-7 